University of Nebraska - Lincoln

DigitalCommons@University of Nebraska - Lincoln

1998

\title{
Estimates of Annual Survival Probabilities for Adult Florida Manatees (Trichechus manatus latirostris)
}

C. A. Langtimm

Sirenia Project, Florida Caribbean Science Center, U.S. Geological Survey, 412 NE 16th Ave, Gainesville, Florida

T. J. O'Shea

Sirenia Project, Florida Caribbean Science Center, U.S. Geological Survey, 412 NE 16th Ave, Gainesville, Florida

R. Pradel Centre D'Ecologie Fonctionnelle et Evolutive, Centre National de la Recherche Scientifique, 1919 route de Mende, 34293 Montepellier CEDEX 5, France

C. A. Beck

Sirenia Project, Florida Caribbean Science Center, U.S. Geological Survey, 412 NE 16th Ave, Gainesville, Florida

Follow this and additional works at: https://digitalcommons.unl.edu/usgsstaffpub

Part of the Earth Sciences Commons

Langtimm, C. A.; O'Shea, T. J.; Pradel, R.; and Beck, C. A., "Estimates of Annual Survival Probabilities for Adult Florida Manatees (Trichechus manatus latirostris)" (1998). USGS Staff -- Published Research. 37. https://digitalcommons.unl.edu/usgsstaffpub/37

This Article is brought to you for free and open access by the US Geological Survey at DigitalCommons@University of Nebraska - Lincoln. It has been accepted for inclusion in USGS Staff -- Published Research by an authorized administrator of DigitalCommons@University of Nebraska - Lincoln. 


\title{
ESTIMATES OF ANNUAL SURVIVAL PROBABILITIES FOR ADULT FLORIDA MANATEES (TRICHECHUS MANATUS LATIROSTRIS)
}

\author{
C. A. Langtimm, ${ }^{1,3}$ T. J. O’Shea, ${ }^{1,4}$ R. Pradel, ${ }^{2}$ and C. A. BecK ${ }^{1,5}$ \\ ${ }^{1}$ Sirenia Project, Florida Caribbean Science Center, U.S. Geological Survey, 412 NE 16th Ave, \\ Gainesville, Florida 32601 USA \\ ${ }^{2}$ Centre D'Ecologie Fonctionnelle et Evolutive, Centre National de la Recherche Scientifique, 1919 route de Mende, \\ 34293 Montepellier CEDEX 5, France
}

\begin{abstract}
The population dynamics of large, long-lived mammals are particularly sensitive to changes in adult survival. Understanding factors affecting survival patterns is therefore critical for developing and testing theories of population dynamics and for developing management strategies aimed at preventing declines or extinction in such taxa. Few studies have used modern analytical approaches for analyzing variation and testing hypotheses about survival probabilities in large mammals. This paper reports a detailed analysis of annual adult survival in the Florida manatee (Trichechus manatus latirostris), an endangered marine mammal, based on a mark-recapture approach. Natural and boatinflicted scars distinctively "marked" individual manatees that were cataloged in a computer-based photographic system. Photo-documented resightings provided "recaptures." Using open population models, annual adult-survival probabilities were estimated for manatees observed in winter in three areas of Florida: Blue Spring, Crystal River, and the Atlantic coast. After using goodness-of-fit tests in Program RELEASE to search for violations of the assumptions of mark-recapture analysis, survival and sighting probabilities were modeled under several different biological hypotheses with Program SURGE. Estimates of mean annual probability of sighting varied from 0.948 for Blue Spring to 0.737 for Crystal River and 0.507 for the Atlantic coast. At Crystal River and Blue Spring, annual survival probabilities were best estimated as constant over the study period at 0.96 (95\% $\mathrm{CI}=0.951-0.975$ and $0.900-0.985$, respectively). On the Atlantic coast, where manatees are impacted more by human activities, annual survival probabilities had a significantly lower mean estimate of $0.91(95 \% \mathrm{CI}=0.887-0.926)$ and varied unpredictably over the study period. For each study area, survival did not differ between sexes and was independent of relative adult age. The high constant adult-survival probabilities estimated for manatees in the Blue Spring and Crystal River areas were consistent with current mammalian life history theory and other empirical data available for large, long-lived mammals. Adult survival probabilities in these areas appeared high enough to maintain growing populations if other traits such as reproductive rates and juvenile survival were also sufficiently high. Lower and variable survival rates on the Atlantic coast are cause for concern.
\end{abstract}

Key words: life history traits; marine mammals; mark-recapture; open population models; photoidentification; sighting probabilities; survival probabilities; Trichechus manatus.

\section{INTRODUCTION}

Many species of large mammals have life histories that include correlated traits such as small litter size, long gestation, long life-span, extended parental care, and high adult survival (Eisenberg 1981, Harvey et al. 1989). These combinations of traits result in low po-

Manuscript received 21 June 1996; revised 17 April 1997; accepted 8 May 1997.

${ }^{3}$ Present address: Piedras Blancas Research Station, California Science Center, U.S. Geological Survey, PO Box 70 San Simeon, California 93452 USA; and Department of Forestry and Wildlife Management, University of Massachusetts, Amherst, Massachusetts 01003 USA.

${ }^{4}$ Present address: Midcontinent Ecological Science Center, U.S. Geological Survey, 4512 McMurry Ave., Fort Collins, Colorado 80525 USA.

${ }^{5}$ Address for reprint requests. tential rates of increase, and can render such populations particularly susceptible to decline or extinction if they are disrupted. The potential rate of increase is most sensitive to changes in adult-survival probabilities, as has been demonstrated for various species, including marine mammals in general (Eberhardt and Siniff 1977, Eberhardt 1985) and manatees in particular (Eberhardt and O'Shea 1995). Despite this sensitivity, tests of hypotheses about factors influencing adult-survival probabilities, based on sound empirical data, are rare for wild populations of large mammals. The lack of comparative data hampers development and testing of hypotheses about population dynamics and the evolution of life history strategies (Harvey et al. 1989, Gaillard et al. 1994). Also, most estimates of survival of large mammals are based on age-at-death life-table approaches that assume stable populations and do not 

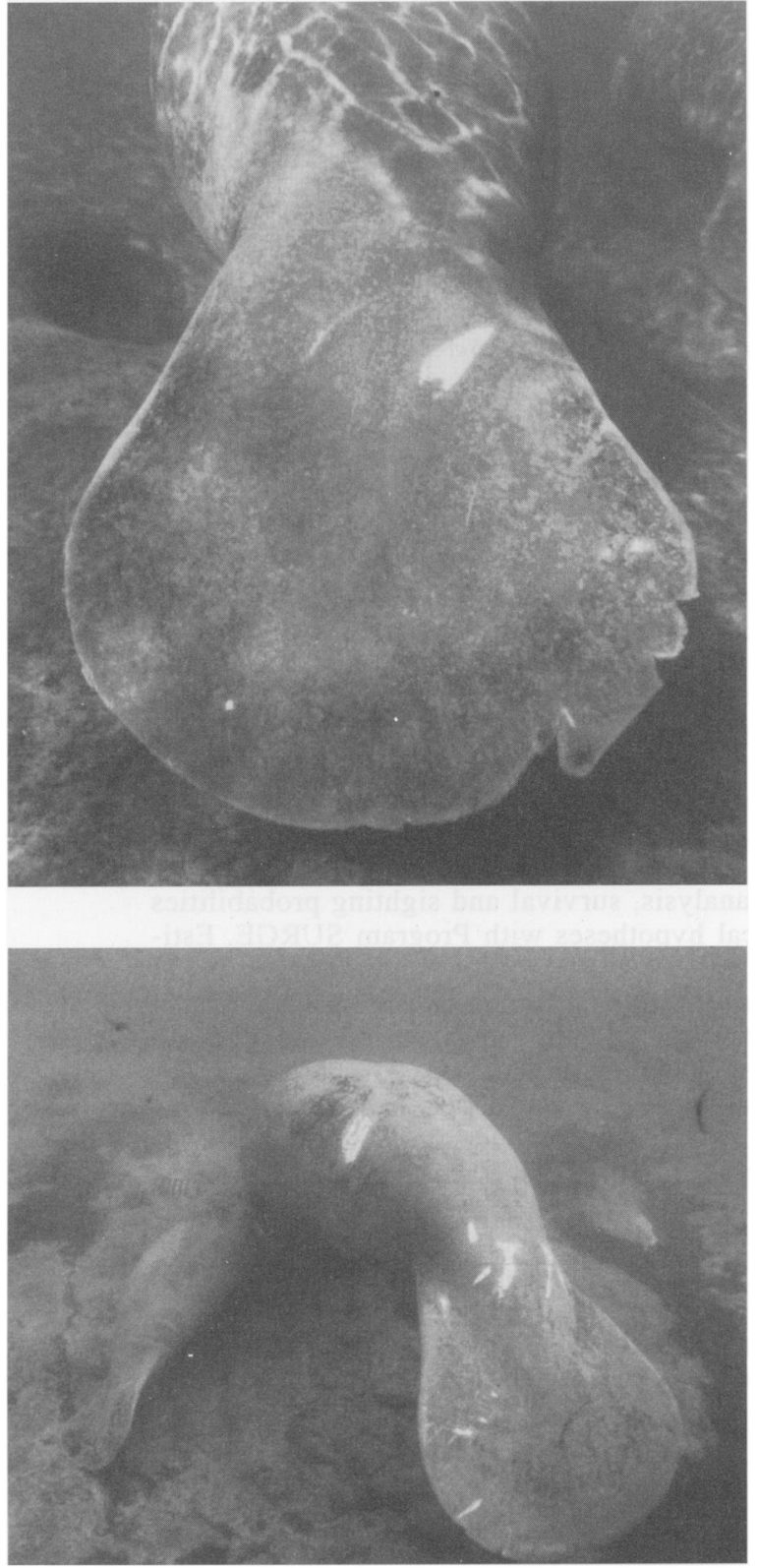

FIG. 1. Examples of scars used to identify individuals in the manatee sighting database. Top: Tail mutilation and healed wounds from boat collisions. Bottom: Healed wounds from boat collisions on the body of an adult female. Note unmarked calf accompanying the female.

allow analysis of variability (Gaillard et al. 1993). We conducted this study to test biological hypotheses regarding variability in adult-survival probabilities of manatees (Trichechus manatus latirostris) in three regions of Florida, and used modern techniques of mark-recapture analyses (Lebreton et al. 1992, 1993, Nichols 1992) applied to extensive photo-identification records of free-ranging individuals. Boat-inflicted scars and natural markings rather than artificial tags were used to identify individuals (Fig. 1). The photographic data originally were collected to document movements between aggregation sites (Reid et al. 1991), yearly return rates to aggregation sites (Rathbun et al. 1990), and reproductive traits such as interbirth interval and age at first reproduction (O'Shea and Hartley 1995, Rathbun et al. 1995, Reid et al. 1995).

The Florida manatee is an important subject for comparative study with other large mammals because of the suite of life history traits associated with its unusual life-style as an obligate aquatic herbivore (O'Shea and Reep 1990). It is also considered one of the most endangered marine mammals in United States waters (U.S. Marine Mammal Commission 1995). Understanding sources of variation in survival of adult Florida manatees has direct implications for management strategies aimed at recovery of their populations. This report also provides a case study of the use of natural markings of individuals for the recapture-based analysis of animal populations. Increasing numbers of field studies report the use of natural markings to identify individuals in the wild in a wide range of taxa for which capture and marking is not desirable or logistically feasible, including cetaceans (Hammond et al. 1990, Gonzalez 1994), pinnipeds (Hiby and Lovell 1990), carnivores (Miththapala et al. 1989), and birds of prey (Bretagnolle et al. 1994). Combining these techniques with modern analytical methods for the study of survival is in early stages of development for most groups.

In a previous study we explored the feasibility of several approaches to estimate survival in Florida manatees, including modifications of the Cormack-JollySeber (CJS) open population model based on markrecapture data (O'Shea and Langtimm 1995). In the case of the manatee data, "marks" are unique patterns of boat-inflicted scars and natural features that are used to identify individuals; subsequent "recaptures" are photographically documented resightings. Our initial findings supported the utility of using mark-recapture analysis and provided the first estimates of adult survival in manatees. In this study, we expanded the analysis to include tests of biological hypotheses on manatee survival using new software tools such as Program SURGE 4.2 (Pradel and Lebreton 1993) and an expanded and revised sighting database. We addressed the following major biological questions. (1) Relatively constant and high annual adult-survival probabilities are life history characteristics common to large mammals (Fowler 1981); are they also found in Florida manatees? (2) If annual survival probabilities have not been relatively constant, have they increased, decreased, or varied in any predictable manner? (3) Is there a difference between sexes in annual adult-survival probabilities, as seen in many marine mammals (Ralls et al. 1980)? (4) Is there any evidence for senescence in Florida manatees? (5) Are there differences in annual adult-survival probabilities among manatees from different geographic regions that may be associated with regional differences in human activities and 
conservation measures? (6) Do annual patterns in mortality data from carcass recoveries vary in association with patterns of survival estimated from resightings of live individuals?

\section{Methods}

\section{Assumptions of mark-recapture analysis}

The basic assumptions of the classic CJS open population model to estimate survival probabilities are: (1) every individual in the data set has the same probability of survival between sampling occasions; (2) every individual has the same probability of being sighted at least once during the sampling interval; (3) the sighting of one individual is not dependent on the sighting of any other individual; (4) every individual is identified correctly; (5) sampling time is negligible. Violations of these assumptions can bias estimates to varying degrees (Carothers 1973, 1979, Pollock et al. 1990). Because we were conducting a retrospective analysis of data not originally collected for survival estimation, to better meet these assumptions we developed conservative criteria to partition individuals into data sets and to select and censor the sighting data. We also tested for violations of some of the assumptions during our statistical analysis.

\section{Manatee aggregations and the focal study areas}

Manatees are included in a small order of aquatic herbivores (Sirenia), whose extant members are confined to warm latitudes. They are generally intolerant of cool water temperatures due to their low metabolic rate and high thermal conductance (Irvine 1983). The Florida manatee, a subspecies of the West Indian manatee, is the northernmost representative of the group, and its annual cycle is dominated by major seasonal shifts in distribution and changes in behavior due to winter temperatures. Aggregations during cold winter weather of 300 or more manatees can form at each of several constant-temperature $\left(\sim 22^{\circ} \mathrm{C}\right)$ springs and industrial warm-water effluents around Florida. Many individuals migrate relatively long distances to reach warm-water refugia (Reid et al. 1991, Ackerman 1995, Reid et al. 1995), and movements to and from the sites are independent among adult individuals (Bengtson 1981). Manatees are not known to form stable social groups as adults (Hartman 1979), and when dispersed during nonwinter seasons the predominant group size observed during aerial surveys is typically one (Irvine et al. 1982).

Winter aggregations provided researchers with access to large numbers of manatees not available at other times or places, and data from aggregation sites within three distinct geographic areas (Crystal River, Blue Spring, and the Atlantic coast) (Fig. 2), were the basis for this analysis. These geographic areas do not define isolated populations of manatees, as individuals can be far-ranging (Reid et al. 1991) and there is no evidence

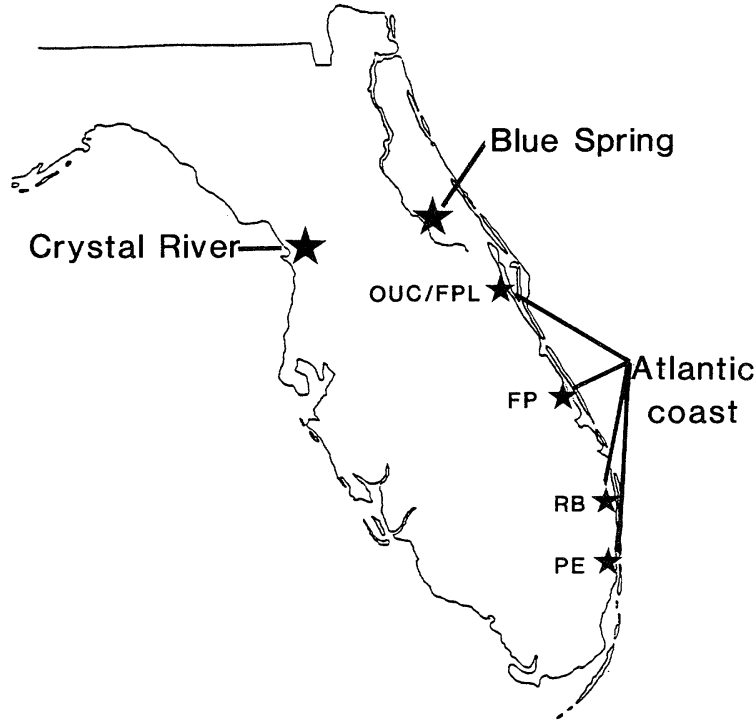

FIG. 2. Map of manatee aggregation sites within the three study areas. OUC, Orlando Utilities Commission Indian River power plant; FPL, Florida Power and Light Corporation Canaveral power plant; FP, Florida Power and Light Fort Pierce power plant; RB, Florida Power and Light Riviera Beach power plant; PE, Florida Power and Light Port Everglades power plant.

for genetic isolation, even between the two coasts of Florida (McClenaghan and O'Shea 1988). However, the areas do show very limited interchange of individuals (Rathbun et al. 1990, Reid et al. 1991), while differing in a number of important characteristics related to habitat quality, protection, and sources of mortality (summarized in detail by O'Shea and Langtimm [1995]) that could result in differences in manatee population parameters. Further subdivisions of manatees that are in substantial isolation from one another or differ markedly in life history are not possible (O'Shea and Langtimm 1995, O'Shea et al. 1995). Therefore, with this study we refer to manatees within each of these geographic regions as a "population.",

Manatees in the Crystal River population frequent two winter refuges on the Gulf coast: the artesianspring-fed Crystal and nearby Homosassa rivers. Individuals are drawn primarily from the colder waters of the Big Bend coast of northwestern peninsular Florida to these natural springs where they are easily photographed underwater. There are large areas of undeveloped habitat within the annual range of the population, some of which is protected; and there has been intensive enforcement of boating and diving regulations at the winter aggregation sites since the late $1970 \mathrm{~s}$ (recreational diving sometimes creates conflicts with manatee conservation). The number of known deaths due to boat strikes and other human-related factors has been low in this region (O'Shea et al. 1985, Rathbun et al. 1990, Ackerman et al. 1995). Aerial-survey counts documented a maximum of 292 individuals in 
the area in winter 1992-1993, and long-term data suggest that the population has increased since the $1960 \mathrm{~s}$ (Rathbun et al. 1990, Ackerman 1995). Identification of individual manatees at Crystal River based on scar patterns extends back to the 1960s (Hartman 1979, Rathbun et al. 1995).

Blue Spring in the St. Johns River of northeastern Florida is a natural spring that draws manatees in winter primarily from the upper St. Johns River system. The population is smaller in number with a maximum count of 88 individuals at the aggregation in 1993-1994 (Ackerman 1995), and individual identifications have been determined on a nearly daily basis in winter since 1978. Within the St. Johns River system there is a moderate amount of undeveloped habitat, but until recently some critical waterways were unprotected. During the winter aggregation period there is strict enforcement of boat-speed zones and diving regulations in the immediate area of the spring. The number of known deaths due to human-related factors as a proportion to total mortality is intermediate to values for the other two study areas (Sirenia Project and Florida Department of Environmental Protection, unpublished data). The number of overwintering manatees has increased since intensive study began in the 1970 s (O'Shea 1988, Ackerman 1995).

On the Atlantic coast manatees aggregate in winter at, and migrate between, numerous natural and manmade warm water sites, but the discharge canals of five coastal power plants have supported the largest aggregations and provided the bulk of the photographic data (Fig. 2). The annual range of the population extends along the entire Atlantic coast of Florida and southern Georgia, and includes areas that are highly developed with extensive boat traffic. Boat speed zones for manatee protection have only recently been implemented beyond the limited areas of the discharge canals, and regulations at winter aggregation sites have not been as well enforced as at Crystal River or Blue Spring. The proportion of deaths due to anthropogenic causes is larger than those observed at the other two study areas (O'Shea et al. 1985, Ackerman et al. 1995). Aerial-survey counts documented at least 888 individuals on the Atlantic coast in January 1992 (Ackerman 1995). Counts at aggregation areas along the Atlantic coast also have increased, but with indications of decreasing rates of population growth since the late $1980 \mathrm{~s}$ (Garrott et al. 1994).

We hypothesized that survival probabilities of adult manatees should differ among these populations, requiring separate data sets and comparative study. Because survival probabilities may differ between sexes (Ralls et al. 1980), we also partitioned individuals by sex within a population. The sighting records available primarily included individuals scarred by healed wounds from encounters with boats. Few animals were marked solely with natural features, and unscarred animals were not represented. We do not know if sighting and survival probabilities among scarred and unscarred manatees are equivalent. No data suggest that there are differences in behavior that would result in differences in resighting or survival. Even if this were true, however, the total number of boat-scarred manatees represents a significant fraction of the population in each of these regions, which is important from the standpoint of population dynamics and conservation.

\section{Data collection and photo-identification}

A photo-catalog was first developed in the late 1970s to gather photo-identification records and long-term observational histories of individually recognizable (scarred and naturally marked) manatees (Reid et al. 1991). Later this catalog evolved into the Manatee Individual Photo-identification System (MIPS), which uses digitized images and PC-based search technologies to assist researchers in identifying possible matches with cataloged individuals (Beck and Reid 1995). The MIPS database is dynamic but currently holds records for over 1000 individuals with over 14000 sightings.

Photographs of manatees in the database were taken by trained staff who have consistently monitored some of the winter aggregation sites since the late 1970s. At most power plants, a telephoto lens was used from dry vantage points to photograph distinct features of manatees at or near the surface, while at clear water sites such as Crystal River and Blue Spring, an underwater camera with a wide angle lens was used by photographers swimming near the manatees. Distinct features and scar patterns common on the tail, back, flanks, head, and flippers of each individual (Fig. 1) were documented with slide transparencies. To be cataloged in the MIPS an individual had to have multiple healed features that were unique and repeatedly recognized, and there had to be complete documentation of the dorsal view of its body, including those parts without scars. Positive resightings of cataloged individuals were made by each photographer by comparing the slide transparency to digitized images in MIPS and archived transparencies representing the complete photo-history of the individual. The database manager corroborated the identifications. Beck and Reid (1995) gave a detailed description of protocols that were used to catalog individuals and collect data.

Errors in identification may have occurred in the database. The most likely sources of error would be either losses or changes of original marks, resulting in low numbers of sightings and an underestimation of survival probabilities (Arnason and Mills 1981); or false positives in which multiple individuals were identified as the same individual, that could result in an overestimation. Although we did not quantify error rate, we believe it was very low and did not produce a serious violation of assumption number four. We used strict, conservative protocols to catalog animals and to accept data, and the possibility of misidentifications 
was reduced further by several factors inherent to the manatee system. The close proximity of photographers to the animals (usually $1-10 \mathrm{~m}$ ) and the general tolerance of manatees to being approached allowed the documentation of close details of features. Only healed features were used as marks, and there was redundancy in identification information in that most cataloged individuals had multiple scars and features distributed over more than one part of the body. Finally, the documentation of newly acquired scars or changes in marking patterns was facilitated by the high return rate of individual manatees each year to the monitored aggregation sites (photo-identification data: Rathbun et al. 1990, 1995, Reid et al. 1991, O'Shea and Hartley 1995; radiotelemetry data: Bengtson 1981, Rathbun et al. 1990, Reid et al. 1995), and the consistent monitoring of these sites by trained and experienced observers.

\section{Censoring data for individual sighting histories}

Not all of the sighting data for each individual in MIPS was included in the analysis. Earlier records in which the animal may not have been of adult status were excluded. We expected survival probabilities to differ among juveniles, subadults, and adults. Markrecapture statistical models were available to estimate and compare survival probabilities among age classes (Pollock et al. 1990, Lebreton et al. 1992, Brownie et al. 1993). Nonetheless, our sighting database of knownage individuals was too small to analyze adequately the survival probabilities of juveniles and subadults, because the animals frequently do not acquire healed scars that can be used as marks until after they are adults. We therefore focused on adult survival and used conservative criteria to define adult status. Individuals were considered adult based on size, reproductive history (females with calves), and/or known age. In instances where no data on size or reproductive history were available, independent animals were classified as adult the third year after first sighting, based on the possibility that on their first sighting they may have been recently weaned subadults. O'Shea and Langtimm (1995) presented a complete discussion of our age classification criteria.

Manatees were photographed at all times of the year, however, for the survival analysis we defined a narrower sampling interval to meet assumption number five and censored the data to include only sightings during a $90-\mathrm{d}$ period each winter when manatees were most readily photographed. Photographing manatees is time-consuming and weather-dependent, and in order to obtain adequate sample sizes, this 90 -d interval was required. Generally, in mark-recapture analysis the desired sampling interval should be negligible compared to the interval between periods to ensure that the assumption of equal probability of survival is not violated. However, when daily mortality probabilities are low, as is the case for manatees, the expected bias from the longer sampling interval should be small (Hargrove and Borland 1994).

The scheduling of the 90-d sample period differed among the three study areas. Cold fronts that trigger manatee aggregations occur earlier in the season at Crystal River and Blue Spring in northern Florida than at the more southern power plants on the Atlantic coast. Traditionally, personnel have concentrated efforts earlier at Crystal River and Blue Spring than on the Atlantic coast. Therefore, we defined the sampling interval for Crystal River and Blue Spring as 15 November to 12 February and for the Atlantic coast as 1 December to 28 February. Differences in the timing of the Crystal River-Blue Spring samples and the Atlantic coast samples should not bias comparisons among sites. The intervals are relatively close in time and the mortality regimes experienced by manatees in each of the study areas should be more closely related to seasonal conditions than to absolute time periods.

We extracted sightings from the photo-identification database using the selected criteria and constructed individual sighting histories. Each sighting history consisted of the sighting (1) or nonsighting (0) of the individual at least once during the 90 -d sampling period for each year during the study. Many animals were sighted multiple times during a period. Examination of the data revealed small sample sizes for some of the earlier years; therefore we restricted the analysis to sightings for winter 1981-1982 through 1992-1993 at Crystal River, winter 1977-1978 through 1992-1993 at Blue Spring, and winter 1984-1985 through 19921993 at the Atlantic coast. The final data set (sighting histories available from C. A. Langtimm) for Crystal River included sighting histories for a total of 234 adults (126 males and 108 females). Blue Spring consisted of 77 adults (54 males and 23 females), and the Atlantic coast data set consisted of 414 adults (84 males, 221 females, and 109 of unknown sex). A large component of the Atlantic coast data set could not be characterized by sex due to the lack of opportunity to observe external genitalia from the shore-based vantage points used by photographers.

\section{Modeling procedures, goodness-of-fit tests, and hypothesis testing}

To model survival and test biological hypotheses regarding survival, we followed the approach outlined by Lebreton et al. (1992). We started with the general CJS model $\left(\phi_{s^{*}} p_{s^{*}}\right)$ [notation for models follows Lebreton et al. 1992], allowing survival $(\phi)$ and sighting $(p)$ probabilities to vary with sex $(s)$ and time $(t)$. This is a reasonable model based on our knowledge of manatee biology. We then assessed the goodness-of-fit (GOF) of the sighting histories for each of the sexes separately, as well as pooled, to the general model. TEST1 in program RELEASE Version 2.7 (Burnham et al. 1987) was used to test for differences in survival and/or sighting probabilities between sexes, while the 
pooled chi-square statistics of TEST2 + TEST3 were used to estimate the overall goodness-of-fit of the data to the CJS model. If the data failed the overall GOF test, we examined the component tests within TEST2 and TEST3 to identify the nature of the excess variation, with the intention of modeling that variation in a more complex model. Component tests in TEST2 provide general evidence for heterogeneity in sighting probabilities, indicative of a "trap effect" or other natural phenomena that mimic genuine trap dependence (Pradel 1993). TEST3 examines possible effects of transients by testing for different probabilities of subsequent resighting between new individuals and previously identified individuals sighted at the same sampling period (Burnham et al. 1987, Pradel et al. 1997).

After assessing GOF, we used Program SURGE 4.2 (Pradel and Lebreton 1993) to construct additional models for each population that were biologically reasonable and based on ecological hypotheses. Using a hierarchical approach beginning with the global CJS model, we successively removed variation from the previous model. Models were constrained by specific factors that we hypothesized affected survival or resighting. From among these models we selected a best model for each population based on Akaike's Information Criterion (AIC). AIC assists the researcher in identifying the most parsimonious model with enough parameters to account for the structure of the data without over-parameterization and loss in precision (Burnham and Anderson 1992, Burnham et al. 1995). We tested the goodness-of-fit of the data to the selected model following the procedures of Lebreton et al. (1992:82). The best model for each population then was used to obtain maximum-likelihood estimates of annual survival probabilities, sighting probabilities, and approximate $95 \%$ confidence intervals $(95 \% \mathrm{CI})$. We tested a specific biological hypothesis with a likelihood ratio test (LRT), comparing the fit of a model that included an effect from a specified factor (the alternative hypothesis) to the fit of the model nested within this alternative model in which the effect under study had been removed (the null hypothesis). If no significant difference between the two models was detected, based on parsimony the null hypothesis model with no effect and fewer parameters was preferred (Lebreton et al. 1992). Differences in survival probabilities among the three study areas were tested with a generalized chi-square statistic (Sauer and Williams 1989) available in Program CONTRAST (Hines and Sauer 1989).

For Blue Spring the CJS model did not fit the data, and attempts to model the excess variation were not totally effective. In the presence of excess variation, variance is underestimated with normal modeling procedures. Therefore we estimated the variance inflation factor (Burnham et al. 1987:246), a parameter indicative of the amount of excess variation present in the data; and in order to reflect more adequately the im-
TABLE 1. Summary of the different models constructed with program SURGE.

\begin{tabular}{|c|c|}
\hline $\begin{array}{c}\text { Model } \\
\text { notation }\end{array}$ & Biological hypothesis \\
\hline$\phi_{s^{*} t} C$ & $\begin{array}{l}\text { Survival probabilities of the sexes vary } \\
\text { independently over time. }\end{array}$ \\
\hline$\phi_{s} C$ & $\begin{array}{l}\text { Survival probabilities are constant over } \\
\text { time, but vary by sex. }\end{array}$ \\
\hline$\phi_{t} C$ & $\begin{array}{l}\text { Survival probabilities are time dependent } \\
\text { only. }\end{array}$ \\
\hline$\phi C$ & $\begin{array}{l}\text { Survival probabilities are constant over } \\
\text { time and sex. }\end{array}$ \\
\hline$\phi_{s^{*} a} C$ & $\begin{array}{l}\text { Survival probabilities vary by sex and the } \\
\text { relative age of individuals since first } \\
\text { sighted. }\end{array}$ \\
\hline$\phi_{a} C$ & $\begin{array}{l}\text { Survival probabilities vary by relative age } \\
\text { of individuals since first sighted. }\end{array}$ \\
\hline$\phi_{f \text { (time trend) }} C$ & $\begin{array}{l}\text { Survival probabilities exhibit a logistic- } \\
\text { linear trend over time. }\end{array}$ \\
\hline$\phi_{f(\text { carcass })} C$ & $\begin{array}{l}\text { Survival probabilities vary as a logistic- } \\
\text { linear function of the number of recov- } \\
\text { ered dead adult manatees. }\end{array}$ \\
\hline$S p_{s^{*} t}$ & $\begin{array}{l}\text { Sighting probabilities of the sexes vary in- } \\
\text { dependently over time. }\end{array}$ \\
\hline$S p_{s}$ & $\begin{array}{l}\text { Sighting probabilities are constant over } \\
\text { time, but vary by sex. }\end{array}$ \\
\hline$S p_{t}$ & $\begin{array}{l}\text { Sighting probabilities are time dependent } \\
\text { only. }\end{array}$ \\
\hline$S p_{t+m}$ & $\begin{array}{l}\text { Sighting probabilities are time dependent } \\
\text { with an additive effect due to Markov- } \\
\text { ian temporary emigration of some indi- } \\
\text { viduals out of the study area. } \dagger\end{array}$ \\
\hline$S p$ & $\begin{array}{l}\text { Sighting probabilities are constant over } \\
\text { time and sex. }\end{array}$ \\
\hline$S p_{f(\text { counts })}$ & $\begin{array}{l}\text { Sighting probabilities vary as a logistic- } \\
\text { linear function of the number of mana- } \\
\text { tees at the aggregation sites as indicated } \\
\text { by aerial survey counts. }\end{array}$ \\
\hline$S p_{f(\mathrm{~d}-\mathrm{day})}$ & $\begin{array}{l}\text { Sighting probabilities vary as a logistic- } \\
\text { linear function of cold weather, as indi- } \\
\text { cated by the number of heating degree- } \\
\text { days below } 18.3^{\circ} \mathrm{C} \text { during the sighting } \\
\text { period. }\end{array}$ \\
\hline
\end{tabular}

Note: $\phi=$ apparent survival probability; $p=$ sighting probability; $S=$ any survival probability model presented in the table; $C=$ any sighting probability model presented in the table.

$\dagger$ Pradel (1993).

precision of the modeling procedures, we incorporated the factor into the calculation of AIC (Anderson et al. 1994), LRT, and 95\% CI (Lebreton et al. 1992:106).

With our models we examined several factors that we expected might affect or vary in association with survival or sighting probabilities of manatees (Table 1). Separate survival models included variation as a function of sex and/or year. The possibility that there was a decreasing or increasing trend in survival probabilities over the years was addressed in a model in which we constrained survival probabilities to vary as a function of increasing time. This time trend model, as well as other models in which we constrained model parameters to be a function of an external covariate, were expressed by Program SURGE in the framework of generalized linear models. A logistic-linear function was used to link the parameters to a linear formula; 
and, similar to regression analysis, two parameters, the slope and $y$-intercept of the formula, were estimated (Lebreton et al. 1992:76-77, Pradel and Lebreton 1993).

We addressed the possibility of senescence in manatees, which might be indicated by a decline in survival probabilities with increasing age, with a model in which survival varied as a function of relative age of adults since they were first "marked" and cataloged into the MIPS system. We did not know the exact ages of individuals, but we could test for a decline in survival with successive resightings (and therefore aging) of individuals.

Prior to this study, necropsy data from the Carcass Recovery Program, a program initiated in 1974 to recover all dead manatees in Florida, was the only source of information about temporal trends in mortality (O'Shea et al. 1985, Ackerman et al. 1995). We tested for congruence between the mortality and survival data with the two larger data sets from Crystal River and the Atlantic coast by constructing a model that included the number of recovered carcasses (data provided by Florida Department of Environmental Protection, Carcass Recovery Program) as a covariate for our yearly survival estimates. Covariate values used in the model were the total number of adult manatee carcasses (total length $276-411 \mathrm{~cm}$ ) recovered each year within each geographic region.

Variation in sighting probabilities was modeled as a function of sex and year. For the Atlantic coast we found lower probabilities of sighting with larger confidence intervals than at the other two study areas. This variability decreases the precision of our survival estimates, so we attempted to further model the variation. Under random temporary emigration, sighting probability is estimated as the product of two probabilities: (1) the probability that an animal is in a sampled area and (2) the probability that an animal is detected given that it is in a sampled area. The probability that a manatee is at a monitored aggregation site depends on winter severity. Manatees gather in larger numbers and for greater lengths of time at warm water sites during colder winters (Hartman 1979, Bengtson 1981, Reynolds and Wilcox 1994). Therefore, we constructed two models in which we represented sighting probabilities as logistic-linear functions of either of two external variables: the degree of winter severity and the actual counts of manatees at the sites during aerial surveys conducted during the sampling period. Winter severity each year was indexed by the total number of heating degree-days over our 3-mo period as calculated by the National Climatic Data Center of the National Oceanic and Atmospheric Administration (NOAA 1985-1993) for the Titusville, Florida weather station. One heating degree-day is accumulated for each degree that the daily mean temperature is below $18.3^{\circ} \mathrm{C}$. This temperature threshold used by NOAA is similar to the threshold below which manatees may become thermally stressed and seek out warmer water (Shane 1984). Annual aerial-survey counts of winter aggregations were available for four of our five photo-identification sites on the Atlantic coast (Fig. 2): OUC, FPL, RB, and PE (J. E. Reynolds III, unpublished reports). Because the number of surveys and the quality of survey conditions varied among sites and years (Reynolds and Wilcox 1994), we used the sum of the average number of manatees present during the surveys at the three sites as an index of the number of manatees available for photoidentification each year.

The probability that a manatee is detected, given it is at a monitored aggregation site, is influenced by the amount of time and effort photographers spend at the sites. Along the Atlantic coast, effort was inconsistent among years due to logistical and budgetary constraints. Ideally, the number of person-hours spent by photographers at each aggregation site each year would provide a covariate to use in a model, but these data were not available in this retrospective analysis. Most photographers collected data on a number of research projects (most notably radio-telemetry) simultaneously with photographing manatees. How their time was partitioned among the projects could not be reconstructed and we did not model effort.

\section{RESULTS}

\section{Crystal River}

The general CJS model fit the data satisfactorily for both sexes (TEST2 + TEST3, males: $\chi^{2}=17.60$, df $=34, P=0.991$; females: $\chi^{2}=22.51$, $\mathrm{df}=30, P=$ 0.830 ). There were no significant differences between sexes in survival and/or sighting probabilities (TEST1: $\chi^{2}=26.33$, df $\left.=20, P=0.16\right)$, which supported pooling the data.

With program SURGE we constructed the series of models outlined in Fig. 3. AIC values indicated that the best model was $\left(\phi p_{t}\right)$; between-year variation in survival probabilities was negligible (i.e., constant survival), while sighting probabilities varied among years. Hypothesis testing with likelihood ratio tests between nested competing models (Table 2) also indicated constant survival among years. Although a logistic-linear trend in survival estimates over the years $\left(\phi_{f(\text { time trend) }}\right.$ $p_{t}$ ) was not rejected when compared to the model with random variation in survival $\left(\phi_{t} p_{t}\right)$, the estimated slope of the time-trend relationship $(-0.082,95 \% \mathrm{CI}=$ $-0.226-0.061)$ was not significantly different from zero $\left(\phi p_{t}\right.$ vs. $\left.\phi_{f(\text { time trend) }} p_{t}\right)$. The constant survival model $\left(\phi p_{t}\right)$ also was not rejected when compared to a model in which survival varied as a logistic-linear function of yearly carcass recovery data $\left(\phi_{f \text { (carcass) }} p_{t}\right)$, although the estimated slope of the carcass-recovery relationship was positive $(0.310,95 \% \mathrm{CI}=0.174-0.445)$. Likelihood-ratio tests supported the inference of no differences between sexes in survival or sighting probabilities that were first identified in the goodness-of-fit 


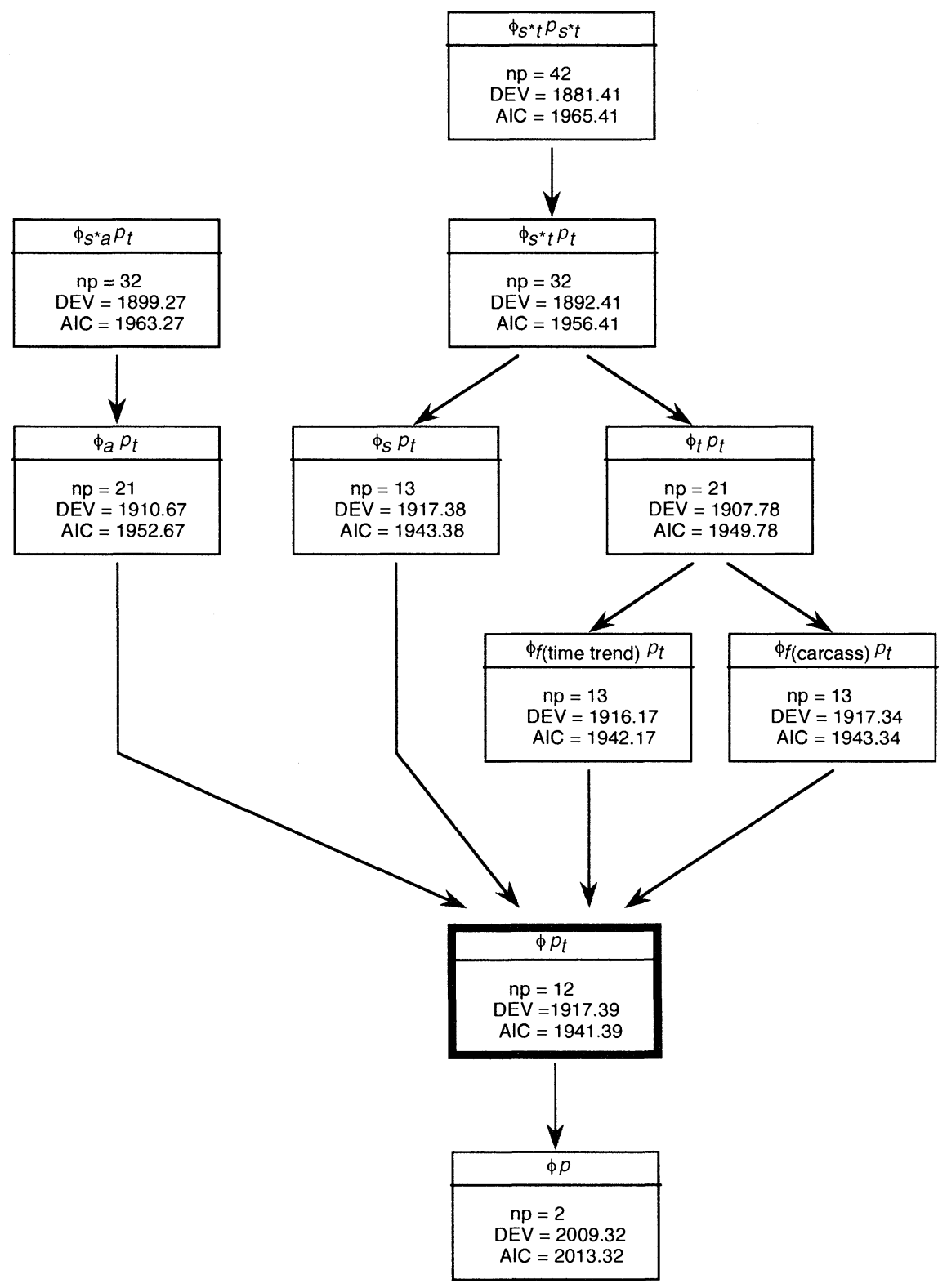

FIG. 3. Model selection scheme for the Crystal River data set. Models were constructed by successively removing variation from the more general model. Each model (see Table 1 for notation) is noted with its number of parameters (np), a relative measure of fit (DEV, the relative deviance), and the Akaike Information Criterion (AIC = DEV +2 np). The arrows point to the more parsimonious model; the model selected (with the lowest AIC) appears in a bold square.

test of RELEASE. Survival probabilities estimated for each sex under the model $\left(\phi_{s} p_{t}\right)$ were $0.965(95 \% \mathrm{CI}$ $=0.945-0.978)$ for males and $0.964(95 \% \mathrm{CI}=0.943-$ 0.978 ) for females. We detected no effect of the relative age of individuals on survival probabilities.

The results of the model selection procedures indicated that the best model to estimate annual adult-survival probabilities for Crystal River manatees was one in which survival was constant over time with variable sighting probabilities $\left(\phi p_{t}\right)$. The model satisfactorily fit the data $\left(\chi^{2}=76.08, \mathrm{df}=93, P=0.943\right)$. The annual survival estimate under this model was 0.965 $(95 \% \mathrm{CI}=0.951-0.975)$. The mean annual sighting probability was $0.737(95 \% \mathrm{CI}=0.660-0.814)$.

\section{Blue Spring}

There were no significant differences between sexes in survival and/or sighting probabilities for Blue Spring manatees (TEST1: $\chi^{2}=21.41, \mathrm{df}=23, P=0.556$ ), allowing the pooling of data, but the CJS model did 
TABLE 2. Tests of hypotheses concerning survival patterns in the Crystal River population.

\begin{tabular}{|c|c|c|c|c|}
\hline Model comparison & $\chi^{2}$ & df & $P$ & Inference \\
\hline$\left(\phi_{s^{*} t} p_{t}\right)$ vs. $\left(\phi_{s^{*} t} p_{s^{*}}\right)$ & 11.00 & 10 & 0.357 & no difference in $p$ between sexes \\
\hline$\left(\phi p_{t}\right)$ vs. $\left(\phi_{s} p_{t}\right)$ & 0.01 & 1 & 0.920 & no difference in $\phi$ between sexes \\
\hline$\left(\phi \mathrm{p}_{t}\right)$ vs. $\left(\phi_{a} p_{t}\right)$ & 6.72 & 9 & 0.666 & no significant effect on $\phi$ due to relative age \\
\hline$\left(\phi_{f \text { time trend) }} p_{t}\right)$ vs. $\left(\phi_{t} p_{t}\right)$ & 8.39 & 8 & 0.396 & $\begin{array}{l}\text { variation in } \phi \text { over time not random, but a logis- } \\
\text { tic-linear fit of time }\end{array}$ \\
\hline$\left(\phi p_{t}\right)$ vs. $\left(\phi_{f(\text { time trend })} p_{t}\right)$ & 1.22 & 1 & 0.269 & $\begin{array}{l}\text { no increasing or decreasing time trend in } \phi \text {; i.e., } \\
\phi \text { is constant over time }\end{array}$ \\
\hline$\left(\phi p_{t}\right)$ vs. $\left(\phi_{f(\text { carcass })} p_{t}\right.$ & 0.05 & 1 & 0.823 & $\begin{array}{l}\text { variation of } \phi \text { with carcass recovery data equiva- } \\
\text { lent to } \phi \text { constant over time }\end{array}$ \\
\hline$(\phi p)$ vs. $\left(\phi p_{t}\right)$ & 91.93 & 10 & $<0.0001$ & significant unspecified variation in $p$ over time \\
\hline
\end{tabular}

Note: The first model (see Table 1 for notation) presented in each comparison represents the null hypothesis model with fewer parameters. The chi-square values are likelihood ratio tests calculated as the difference in deviances between two nested, competing models (Fig. 3). The number of degrees of freedom is given by the difference in parameters estimated by each model.

not satisfactorily fit the data (TEST2 + TEST3, sexes pooled: $\chi^{2}=230.22$, df $\left.=42, P<0.0001\right)$. Examination of the component tests of TEST3 showed an effect of transients on the sighting histories of males (TEST3.SR [components with enough data], males: $\chi^{2}$ $=25.23, \mathrm{df}=10, P=0.005$. Females: $\chi^{2}=5.83, \mathrm{df}$ $=5, P=0.323$ ). Individuals have been identified at Blue Spring in one winter that then left the area and were never seen again (Sirenia Project, unpublished data). There was also an effect similar to trap dependence (TEST2, sexes pooled: $\chi^{2}=134.23, \mathrm{df}=17, P$ $<0.0001)$. Because individual manatees are only photographed and not physically captured, the test in this case detects a natural phenomenon that mimics trap dependence, i.e., Markovian temporary emigration outside of the study area (Sandland and Kirkwood 1981, Pradel 1993, Kendall et al. 1997). Under this type of temporary emigration the probability of an animal being sighted in a given year depends on whether or not the individual was sighted the previous year. Although the majority of manatees sighted at Blue Spring are regular winter residents, several individuals are known only to sporadically overwinter at the aggregation site (Sirenia Project, unpublished data). Thus, individuals sighted one year have a high probability of being seen the following year; whereas individuals not sighted have a much lower resighting probability.

To better account for the effect of transients we dropped the first sighting from each individual sighting history (Paradis et al. 1993, Pradel et al. 1997); this left us with data for winter 1978-1979 through 19921993. The revised data set was insufficient for accurate GOF tests. Visual examination of the component contingency tables, with sufficient data to run TEST2, consistently showed fewer than expected resightings of individuals the following year, indicating that an effect similar to "trap shyness" was still a problem. The new data set also did not fit the CJS model (TEST2 + TEST3 [components with enough data]: $\chi^{2}=81.73, \mathrm{df}$ $=24, P<0.001)$. The estimated variance inflation factor for the data was 3.406 . We then constructed the series of models outlined in Fig. 4, that included an attempt to model the apparent trap effect $\left(\phi p_{t+m}\right)$ following procedures outlined by Pradel (1993).

AIC values indicated that the best model was $(\phi p)$, constant survival and sighting probabilities over time (Fig. 4). Hypothesis testing with likelihood ratio tests between nested competing models (Table 3) also indicated constant survival and sighting probabilities among years. The model that included apparent trap dependence $\left(\phi p_{t+m}\right)$ proved no better in describing the variation in the data than the simpler model $\left(\phi p_{t}\right)$. There was no significant difference in survival between the sexes. Survival probabilities estimated for each sex under the model $\left(\phi_{s} p_{t}\right)$ were $0.969(95 \% \mathrm{Cr}=0.893$ $0.991)$ for males and $0.941(95 \% \mathrm{CI}=0.774-0.987)$ for females. There was no apparent increasing or decreasing logistic-linear trend in survival over time, as the estimated slope of the trend $(-0.086,95 \% \mathrm{CI}=$ $-0.367-0.194)$ was not significantly different from zero $\left(\phi p_{t}\right.$ vs. $\left.\phi_{f(\text { time trend })} p_{t}\right)$. There was also no effect due to the relative age of individuals since first sighted $\left(\phi_{a} p_{t}\right)$.

The results of the model-selection procedures indicated that the best model to estimate annual adult-survival probabilities for Blue Spring manatees was one in which survival and sighting probabilities were constant over time $(\phi p)$. The annual survival estimate under this model was $0.961(95 \% \mathrm{CI}=0.900-0.985)$. The estimated annual sighting probability was 0.948 (95\% $\mathrm{CI}=0.882-0.978)$.

\section{Atlantic Coast}

There were no significant differences in survival and/or sighting probabilities between known males and females (TEST1: $\chi^{2}=11.33$, $\mathrm{df}=15, P=0.7285$ ), so we pooled the data to include both sexes, as well as those adults whose sex had not been determined. The CJS model satisfactorily fit the data for all adults pooled (TEST2 + TEST3: $\chi^{2}=39.03$, df $=41, P=0.559$ ).

We then constructed the series of models outlined in Fig. 5. Differences between sexes could not be addressed because a large number of individuals were of unknown sex. AIC values indicated that the best model 


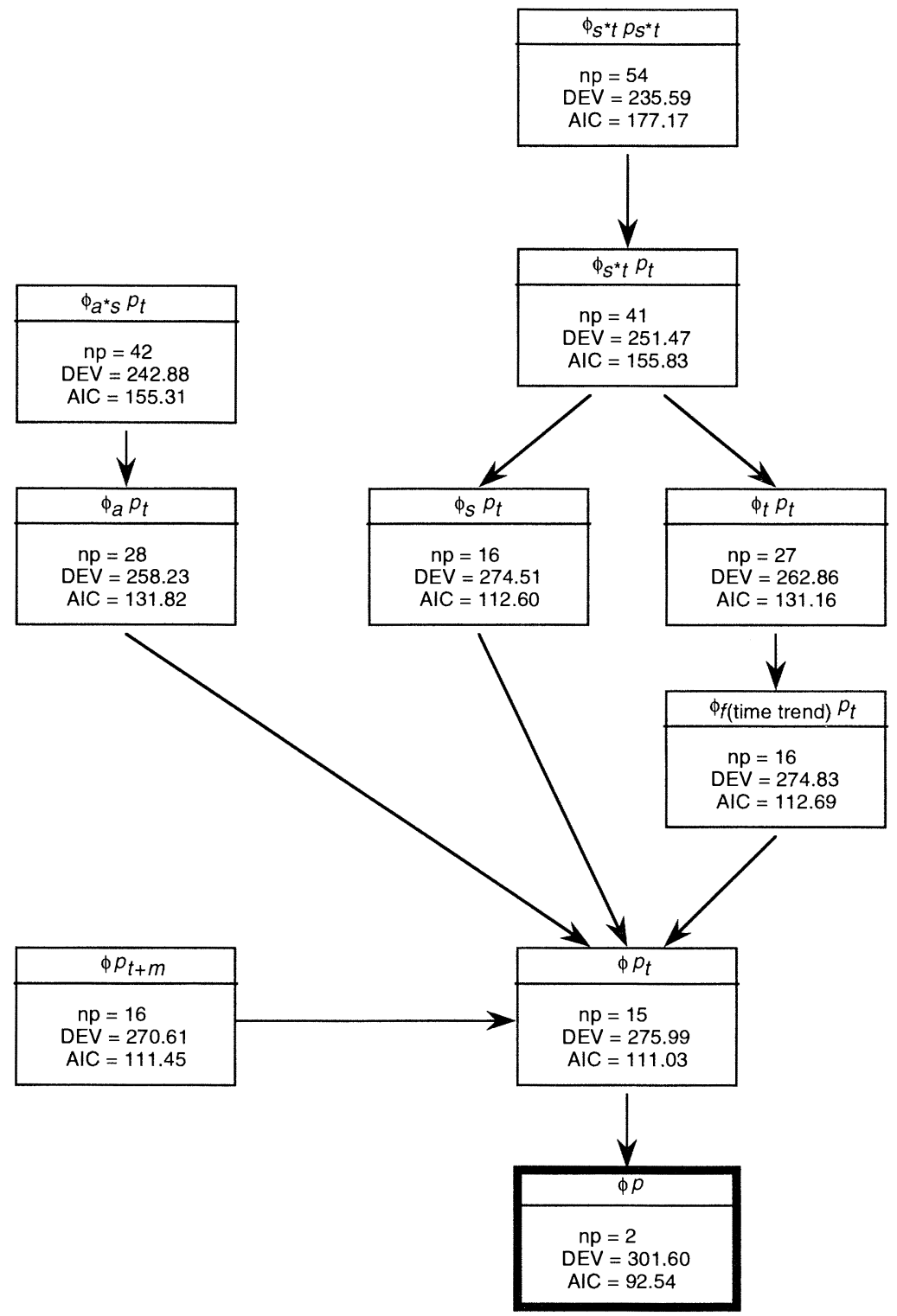

FIG. 4. Model selection scheme for the Blue Spring data set (see Table 1 for notation and Fig. 3 for explanations). The values for DEV and AIC are adjusted with a variance inflation factor to reflect lack of fit of the data to the CJS model.

TABLE 3. Tests of hypotheses concerning survival patterns in the Blue Spring population.

\begin{tabular}{lcrrl}
\hline \hline Model comparison & $F$ & \multicolumn{1}{c}{$\mathrm{df}$} & \multicolumn{1}{c}{$P$} & Inference \\
\hline$\left(\phi_{s^{* t}} p_{t}\right)$ vs. $\left(\phi_{s^{* t}} p_{s^{*}}\right)$ & 0.352 & 13,24 & 0.973 & no difference in $p$ between sexes \\
$\left(\phi p_{t}\right)$ vs. $\left(\phi_{s} p_{t}\right)$ & 0.435 & 1,24 & 0.516 & no difference in $\phi$ between sexes \\
$\left(\phi p_{t}\right)$ vs. $\left(\phi_{a} p_{t}\right)$ & 0.389 & 13,24 & 0.960 & no significant effect on $\phi$ due to relative age \\
$\left(\phi p_{t}\right)$ vs. $\left(\phi_{f(\text { time trend) }} p_{t}\right)$ & 0.341 & 1,24 & 0.565 & no increasing or decreasing time trend in $\phi ; i . e ., \phi$ is \\
$\left(\phi p_{t}\right)$ vs. $\left(\phi p_{t+m}\right)$ & 1.580 & 1,24 & 0.221 & constant over time \\
$(\phi p)$ vs. $\left(\phi p_{t}\right)$ & 0.580 & 13,24 & 0.846 & no significant effect due to trap dependence \\
\hline
\end{tabular}

Note: The first model (see Table 1 for notation) presented in each comparison represents the null hypothesis model with fewer parameters. Because of the lack of fit of the data to the CJS model, two nested, competing models (Fig. 4) are compared by treating differences in deviance, divided by the number of parameters and by the variance inflation factor, as $F$ statistics (Lebreton et al. 1992:106). 


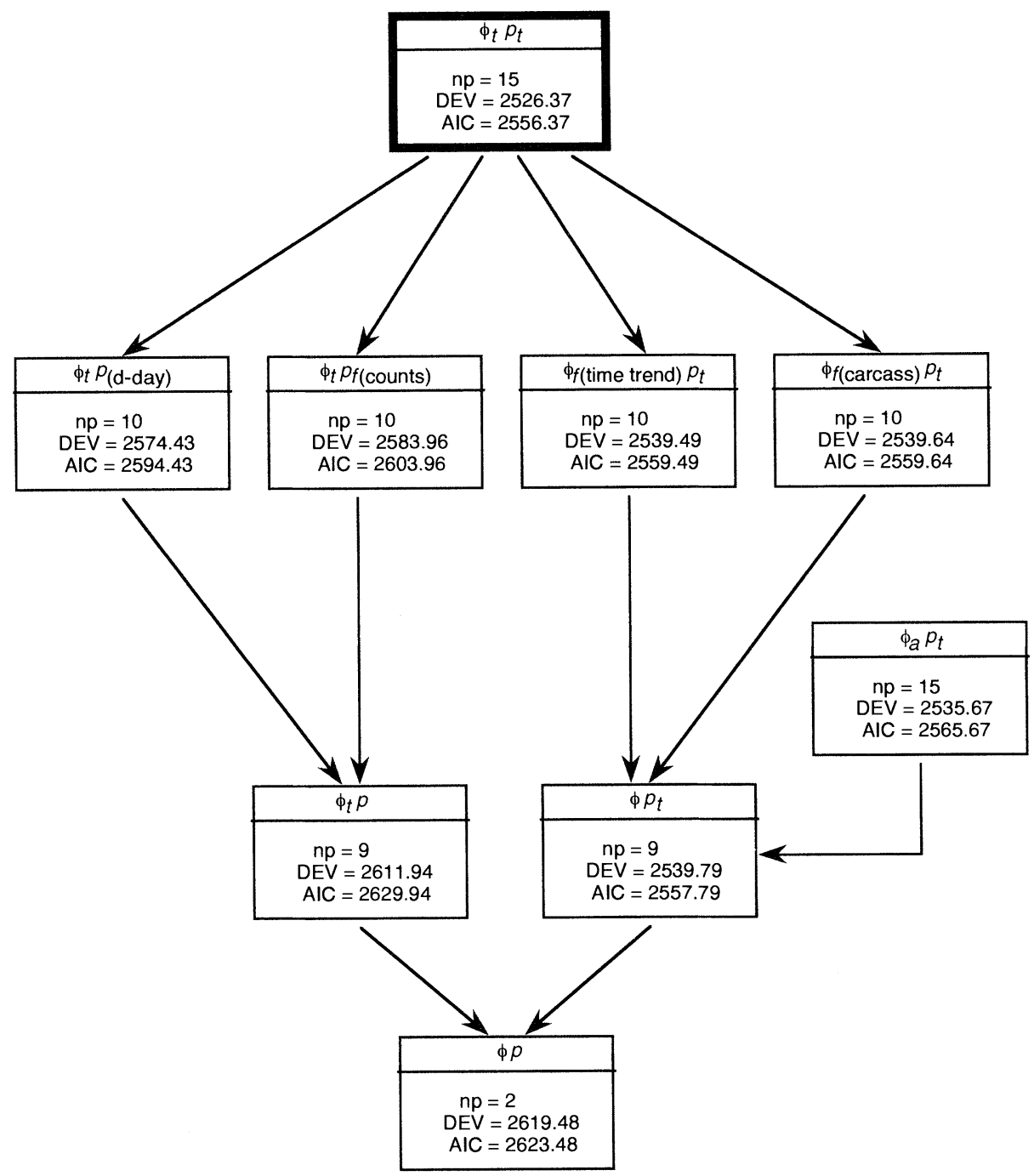

FIG. 5. Model selection scheme for the Atlantic coast data set (see Table 1 for notation and Fig. 3 for explanations).

was $\left(\phi_{t} p_{t}\right)$, in which both survival and sighting probabilities varied among years. All of our attempts to correlate the variation of $\phi$ and $p$ with various factors were unsuccessful (Fig. 5). Likelihood ratio tests (Table 4) consistently revealed significant unspecified temporal variation. Sighting probabilities were not associated with either of the two different variables that were indicative of the availability of manatees each year for capture on photographs: aerial-survey counts of manatees at the aggregation sites $\left(\phi_{t} p_{f(\text { counts })}\right)$ or the number of heating degree-days during the sampling period $\left(\phi_{t} p_{f(\mathrm{~d}-\mathrm{day})}\right)$. To model sighting probabilities realistically, it appears that some index of effort to photograph manatees also would be necessary.

Likelihood ratio tests (Table 4) revealed significant temporal variation in survival probabilities. There was no evidence of a time trend showing increasing, decreasing or constant survival probabilities ( $\phi_{f(\text { time trend) }}$ $p_{t}$ vs. $\left.\phi_{t} p_{t}\right)$. When the data were constrained to the time-trend model $\left(\phi_{f(\text { time trend })} p_{t}\right)$, the estimated slope of the trend $(-0.051,95 \% \mathrm{Cl}=-0.232-0.129)$ was not significantly different from zero $\left(\phi p_{t}\right.$ vs. $\left.\phi_{f(\text { time trend })} p_{t}\right)$, indicating that survival probabilities were indeed neither increasing or decreasing but varying randomly around the mean. Survival probabilities did not vary with relative age $\left(\phi_{a} p_{t}\right)$, and there was no logisticlinear relationship with the number of carcasses recovered each year $\left(\phi_{t} p_{t}\right.$ vs. $\left.\phi_{f(\text { carcass }} p_{t}\right)$. The estimated slope of the carcass-recovery relationship was 0.0066 $(95 \% \mathrm{CI}=-0.028-0.041)$.

The results of the model selection procedures indicated that the best model to estimate annual adult-survival probabilities for Atlantic coast manatees was one in which survival and sighting probabilities both varied over time $\left(\phi_{t} p_{t}\right)$. The mean annual survival estimate under this model was $0.907(95 \% \mathrm{CI}=0.887-0.926)$. 
TABLE 4. Tests of hypotheses concerning survival patterns in the Atlantic coast population.

\begin{tabular}{|c|c|c|c|c|}
\hline Model comparison & $\chi^{2}$ & df & $P$ & Inference \\
\hline$\left(\phi_{t} p_{f(\text { counts })}\right.$ vs. $\left(\phi_{t} p_{t}\right)$ & 57.59 & 5 & $<0.0001$ & $\begin{array}{l}\text { significant random variation in } p \text {; no correlation of } \\
\text { the variation in } p \text { with the number of manatees } \\
\text { counted at the aggregation sites during aerial sur- } \\
\text { vey counts }\end{array}$ \\
\hline$\left(\phi_{t} p_{f(\mathrm{~d} \text {-day })}\right.$ vs. $\left(\phi_{t} p_{t}\right)$ & 48.06 & 5 & $<0.0001$ & $\begin{array}{l}\text { significant random variation in } p \text {; no correlation of } \\
\text { the variation in } p \text { with heating degree-days. }\end{array}$ \\
\hline$\left(\phi_{t} p\right)$ vs. $\left(\phi_{t} p_{t}\right)$ & 85.57 & 6 & $<0.0001$ & $\begin{array}{l}\text { significant random variation in } p ; p \text { is not constant } \\
\text { over time }\end{array}$ \\
\hline$\left(\phi_{f(\text { time trend) }} p_{t}\right)$ vs. $\left(\phi_{t} p_{t}\right)$ & 13.12 & 5 & 0.022 & $\begin{array}{l}\text { significant random variation in } \phi ; \text { no linear trend in } \\
\phi \text { over time }\end{array}$ \\
\hline$\left(\phi p_{t}\right)$ vs. $\left(\phi_{f(\text { time trend })} p_{t}\right.$ & 0.30 & 1 & 0.584 & no increasing or decreasing time trend in $\phi$ \\
\hline$\left(\phi_{f \text { carcass }} p_{t}\right)$ vs. $\left(\phi_{t} p_{t}\right)$ & 13.27 & 5 & 0.021 & $\begin{array}{l}\text { significant random variation in } \phi ; \text { no correlation of } \phi \\
\text { with carcass recovery data }\end{array}$ \\
\hline$\left(\phi_{a} p_{t}\right)$ vs. $\left(\phi p_{t}\right)$ & 4.12 & 6 & 0.660 & no significant effect on $\phi$ due to relative age \\
\hline
\end{tabular}

Note: The first model (see Table 1 for notation) presented in each comparison represents the null hypothesis model with fewer parameters. The chi-square values are likelihood ratio tests calculated as the difference in deviances between two nested, competing models (Fig. 5). The number of degrees of freedom is given by the difference in parameters estimated by each model.

The estimated mean annual sighting probability was $0.507(95 \% \mathrm{CI}=0.426-0.588)$.

\section{Comparisons among populations}

Crystal River and Blue Spring manatees showed negligible variation in survival probabilities over time, while Atlantic coast manatees showed significant temporal variation with a mean annual survival probability that was lower than that estimated for the other two populations (Table 5). There was no significant difference in annual adult-survival probabilities between Crystal River and Blue Spring manatees $\left(\chi^{2}=0.044\right.$, df $=1, P=0.833$ ), but a significant difference was found between Crystal River and the Atlantic coast $\left(\chi^{2}\right.$ $=25.92, \mathrm{df}=1, P<0.0001)$ and between Blue Spring and the Atlantic coast $\left(\chi^{2}=7.05\right.$, df $\left.=1, P=0.0079\right)$.

\section{DISCUSSION}

\section{Concordance with life history theory}

The high annual adult-survival probabilities estimated for manatees at Blue Spring and Crystal River, the two sites with the greatest protection from human impact, are consistent with the high probabilities estimated for other large mammals (Harwood and Prime

TABLE 5. Summary of annual adult survival probability estimates for the three populations.

\begin{tabular}{lccc}
\hline \hline Population & $\hat{\phi}$ & $\widehat{\mathrm{SE}}$ & $95 \% \mathrm{CI}$ \\
\hline Crystal River & 0.965 & 0.006 & $0.951-0.975$ \\
Blue Spring $\dagger$ & 0.961 & 0.018 & $0.900-0.985$ \\
Atlantic Coast & $0.907 \ddagger$ & 0.010 & $0.887-0.926$ \\
\hline
\end{tabular}

Note: The generalized chi-square statistic (Sauer and Williams 1989) showed no significant difference in survival rates between the Crystal River and Blue Spring populations, but significant differences between Crystal River and the Atlantic coast and between Blue Spring and the Atlantic coast.

$\dagger \widehat{\mathrm{SE}}$ and approximate $95 \% \mathrm{CI}$ modified with a variance inflation factor to reflect lack of fit.

$\ddagger$ Value is the mean of the annual estimates.
1978, Buckland 1990, Olesiuk et al. 1990, Amstrup and Durner 1995). Comparative studies have demonstrated that large mammals in general have higher survival probabilities than small mammals (Millar and Zammuto 1983, Harvey and Zammuto 1985). Furthermore, after removing effects of body size, high adultsurvival probabilities are correlated with other life history parameters characteristic of manatees, such as small litter size, long gestation, older age at weaning, and long maximum life span (Harvey et al. 1989).

Relatively constant adult survival over time is a life history characteristic common to large mammals (Fowler 1981), and vertebrates in general (Charnov 1986), and was demonstrated in our analysis as a feature of manatees from Blue Spring and Crystal River. Adult large mammals are relatively insensitive to environmental fluctuations in their preferred habitats compared to juveniles and small, short-lived mammals. Fecundity and juvenile survival probabilities are usually more severely affected than adult survival in populations under environmental stress (Eberhardt 1977, Benton and Grant 1996). The variable survival probabilities estimated for adults of the Atlantic coast are not characteristic of large mammals in stable environments and are cause for concern. Indeed, if the environment affecting adult survival continues to fluctuate over an extended period of time, it could affect the selection pressures operating on other life history traits and the fitness of individuals in the population (Benton et al. 1995, Benton and Grant 1996).

The lack of sex-specific differences in survival of adult manatees is also consistent with mammalian life history theory. Although in many mammalian species males have higher mortality rates than females (Ralls et al. 1980), this effect is often considered a correlate of mating strategies evolved through sexual selection (Trivers 1972). Male-male competition for access to breeding females can result in larger size in males, 
other forms of sexual dimorphism, and differential adult mortality (Ralls et al. 1980, Clutton-Brock et al. 1982, Promislow 1992). Fierce physical encounters observed in highly polygynous species, such as northern elephant seals (Mirounga angustirostris) (Le Boeuf 1974) and red deer (Cervus elaphus) (Clutton-Brock et al. 1982), do not occur in manatees. The life history of manatees is based on an abundant but relatively lowquality food resource of aquatic plants that does not allow selection for resource-based polygyny (O'Shea and Reep 1990). The mating system is essentially an evolutionary "default" strategy of promiscuity. There is an absence of dimorphic characters, and females are slightly larger than males (T. J. O'Shea and H. I. Kochman, unpublished data), a trait that in other mammals can be related to advantages for maternal care under relaxed sexual selection (Ralls 1976).

The existence of senescence has generally been acknowledged by mammalian population ecologists (Caughley 1966, Eberhardt 1985). Only recently, however, has it been statistically detected in some wild populations of mammals (Gaillard et al. 1993, Gaillard et al. 1994), although the evidence of its pervasiveness among mammals has been questioned (Gaillard et al. 1994). We did not detect any significant decrease in survival probabilities with age that might indicate senescence. This may be due to a naturally low rate of senescence in manatees, or to shortcomings of the analysis. Other mammals with low rates of senescence generally also have life history traits similar to those of manatees: large body mass, lengthy gestation, and small litter size (Gaillard et al. 1994). Statistical methods similar to ours were employed by Gaillard et al. (1993) to detect senescence in roe deer, but the cohorts consisted of known-age individuals. Our analysis tested for differences in survival probabilities as a function of age since first marked, and true age effects may have been masked. The relatively limited duration of our study may also be a problem (Loison et al. 1994). Longterm monitoring of long-lived species with mark-recapture techniques is required to demonstrate a decrease in survival with age (Wooller et al. 1992). Our study with only $13 \mathrm{yr}$ of sighting data is short relative to the maximum estimated life span of $59 \mathrm{yr}$ in manatees (Marmontel 1995). Further monitoring of knownage animals is required to assess accurately the possibility of senescence in Florida manatees.

Our study empirically corroborates several patterns predicted for large mammals by contemporary life history theory. Although no patterns were unexpected, the survival estimates of manatees are an important contribution to the available comparative data for several reasons. First, the sirenian life-style as an aquatic herbivore is unique among mammals investigated thus far. Second, few estimates are available for mammals with such potential longevity. Most estimates have been based on one of two methods: (1) an age-at-death lifetable approach (killer whales, Olesiuk et al. 1990; Af- rican elephant, Laws 1966), that assumes a stable population and does not allow analysis of variability; or (2) on radio-telemetry studies (grizzly bears, Eberhardt et al. 1994; polar bears, Amstrup and Durner 1995) that logistically are restricted to monitoring survival of a smaller number of individuals and following them for a shorter period of time. Third, our empirical study is one of the few to test hypotheses concerning variation in survival patterns of large mammals with rigorous mark-recapture statistical methods (Gaillard et al. 1993). Our sample sizes were large with very high sighting probabilities, which increased the precision of our estimates (Pollock et al. 1990), and we tested for violations of the assumptions of the analysis. Finally, our study is based on the identification of individuals from naturally occurring marks, allowing collection of capture and recapture data among freely ranging individuals under the least invasive circumstances.

\section{Comparisons of estimates among geographic regions: implications for conservation}

The lower and variable adult-survival probabilities estimated for manatees of the Atlantic coast area are not consistent with probabilities expected of large mammals in a stable environment. Mortality risks to manatees from boat strikes, other factors, and habitat degradation are higher on the Atlantic coast than at Crystal River or Blue Spring. The implication for conservation is straightforward: managers should attempt to achieve adult-survival probabilities throughout the range of the Florida manatee similar to those estimated for the populations at Crystal River and Blue Spring.

Crystal River and Blue Spring have been in the vanguard of manatee conservation efforts, based on strong legislation by the State of Florida, as well as Federal protection under the U.S. Endangered Species Act of 1973 and Marine Mammal Protection Act of 1972. At Crystal River and Blue Spring, areas of nonwinter habitat include significant undeveloped shoreline set aside for conservation, and the winter aggregation sites are legally designated sanctuaries, well-protected from boat traffic for $>15 \mathrm{yr}$ (deaths from collisions with boats constitute a major proportion of causes of death in adult Florida manatees and enactment of boat-speed zones for manatee protection has been a cornerstone of manatee conservation efforts [O'Shea et al. 1985, Ackerman et al. 1995, O'Shea 1995]). Over this same period, high adult survival has been accompanied by the recovery of relatively low proportions of carcasses indicating death due to anthropogenic causes, particularly at Crystal River (O'Shea et al. 1985, Ackerman et al. 1995), and for the past $25 \mathrm{yr}$ these two areas have shown steadily increasing numbers of wintering manatees (Ackerman 1995). Population models based on reproductive traits observed at these sites, juvenile survival estimates, and adult-survival probabilities similar to those estimated here implied finite rates of increase of 1.06-1.07, whereas a similar model for the Atlantic 
coast suggested a lower finite rate of increase of just 1.01 (Eberhardt and O'Shea 1995).

As we have shown, on the Atlantic coast annual adult-survival probabilities were significantly lower, and the proportion of recovered carcasses with death due to anthropogenic causes was much higher, than at the other two sites (Ackerman et al. 1995); an increasing trend in counts may have leveled off since the late 1980s (Garrott et al. 1994). Correspondingly, winter aggregation sites of manatees on the Atlantic coast occur in some of the most urbanized habitats in the southeastern United States. Undeveloped conservation areas are discontinuous, and only in recent years have specific manatee protection measures been implemented in summer habitats. Boat-speed zone enforcement at winter aggregations has been less intensive than at Crystal River and Blue Spring. Efforts to increase adult survival of manatees by decreasing human-related mortality must be stepped up to levels commensurate with those at Crystal River and Blue Spring. Levels of reproduction estimated for manatees within each region appear to be comparable (Reid et al. 1995), and increasing adult-survival probabilities on the Atlantic coast will promote more rapid population growth and eventual recovery from endangered status.

A second implication for conservation and management is the lack of association we found between annual adult-survival probabilities and the total number of recovered adult carcasses. Carcass counts have been used for years as presumptive indices of mortality in the Florida manatee population (Eberhardt and O'Shea 1995), but as pointed out by O'Shea and Langtimm (1995) and Eberhardt and O'Shea (1995), not all carcasses are found; and carcass counts may vary with changes in manatee population size, changes in mortality rates, and changes in rates of discovery and reporting (through changing public awareness, numbers of people living near and boating on the coasts, and other factors affecting recovery effort). Carcass recovery allows determination of factors that are important for management policies, such as specific causes of death (Ackerman et al. 1995), but our work suggests that calculation and modeling of survival probabilities based on photo-identification efforts provide a more direct and less ambiguous measure for helping managers draw inferences about population status, particularly when used in combination with population modeling (Eberhardt and O'Shea 1995).

\section{The Manatee Individual Photo-identification database: inherent value and current limitations}

Our study has demonstrated the value of the manatee sighting database for estimating survival probabilities and testing hypotheses concerning factors affecting survival in Florida manatees. Although this was a retrospective analysis, the consistent collection of sighting data over the years, in conjunction with our conservative criteria to select and censor data, resulted in survival estimates that should be unbiased with good precision.

Crystal River provided the best data set for estimating survival probabilities and testing hypotheses concerning factors affecting survival. Sample size was large, sighting probabilities were high, and the data adequately fit the general CJS model. Assuming that efforts to photograph at the Crystal River aggregations continue over the coming years, the value of the data set for further long-term studies of survival patterns in Florida manatees, particularly regarding senescence, should increase.

In contrast, data for the Blue Spring population violated the assumption of equal probability of sighting among individuals, but the estimation procedures should have been robust. Simulation studies have shown that heterogeneous capture probabilities are relatively unimportant when capture probabilities are high (Carothers 1973, 1979), and the annual sighting probabilities at Blue Spring were very high (0.948 under model $[\phi p])$. A $95 \%$ annual sighting probability over a 14-yr period is unique in mark-recapture studies of free-ranging large mammals. Nonetheless, heterogeneity in sighting probabilities among individuals, in conjunction with small sample sizes, severely limited the power of tests to detect differences between competing models and hypotheses. As the manatees from this site continue to be monitored, large increases in the population are not anticipated. Undoubtedly, the site in the future will provide data for good estimates for comparisons with other regions, but discerning patterns of variation in survival probabilities with markrecapture models may be difficult.

Data from the Atlantic coast aggregations provided good estimates of annual survival probabilities, but posed the greatest challenge to modeling patterns of variation. Sample size was large with a mean annual sighting probability of 0.507 , that, although lower than the probabilities for Blue Spring and Crystal River, was higher than those found for mark-recapture studies of most other species of large mammals. There were no detectable violations of assumptions, and the data adequately fit the general model. However, we were unable to model variation in any predictable manner. Two problems hampered our efforts and should be the focus of future data acquisition and analysis. First, more information on the environmental factors that affect survival on the Atlantic coast is needed to construct models that more realistically account for the variation. Based on carcass recovery data, it is known that adult deaths due to boat collisions are more common on the Atlantic coast than at Crystal River or Blue Spring (O'Shea et al. 1985, Ackerman et al. 1995), but no covariate measures representative of annual variation in risk due to collisions (such as annual indices of boat usage) are available. Furthermore, risk undoubtedly varies depending on location and the amount of boat traffic. Radio-tracking of individuals has shown that 
some manatees migrate long distances on the Atlantic coast, whereas others do not (Reid et al. 1995). It is unknown how extensively migratory patterns differ among individuals, and presently there are no good indices that can be used to partition individuals into more homogenous groups that frequent the same areas. In this study we assumed the large sample from the Atlantic coast was a random sample of individuals with different migration patterns. The results of the goodness-of-fit tests supported this assumption, and our estimates should be valid for comparisons with manatees in other regions. Nevertheless, until individual variation in migration patterns is better understood, the broad area over which manatees are distributed will continue to hamper efforts to establish correlation between variation in survival and specific environmental factors with mark-recapture methods.

A second modeling problem with the Atlantic coast data is that our survival estimates covered only $8 \mathrm{yr}$, and this time scale may not be adequate for an analysis of variability. Factors affecting survival are more complex, and most likely more variable, on the highly developed Atlantic coast than at Crystal River or Blue Spring. Winter thermal refuges on the Atlantic coast are in urban areas and are subject to artificial interruptions that do not occur at Crystal River or Blue Spring (O'Shea et al. 1985, Ackerman et al. 1995). Furthermore, conservation measures protecting manatees have differed along the coast as they have been implemented on a county-by-county basis. As individuals in this population continue to be monitored and photographed, more well-defined patterns may emerge.

Long-term studies of marked populations are essential for answering many questions fundamental to our understanding of population biology. Only recently have long-term studies allowed the assessment of the importance of density-dependent factors on population fluctuation and life history traits of ungulates (Saether 1997), while long-term studies of seabird populations have begun to reveal trends in age-specific survival (Wooller et al. 1992). The manatee-sighting database is dynamic and growing, and will continue to be an important source of information to test hypotheses about factors affecting not only survival, but also reproduction, movement patterns, and other aspects of population dynamics.

\section{ACKNOWLEDGMENTS}

We thank all of the photographers who contributed to the manatee photo-identification database over the years, but most especially K. Abbott, R. K. Bonde, K. Curtin, D. E. Easton, W. C. Hartley, J. A. Powell, G. B. Rathbun, J. P. Reid, S. H. Shane, M. M. Suarez, S. L. Tyson, J. A. Valade, J. R. Wilcox, and B. J. Zoodsma. Without their dedication this database would not exist. Photography at winter aggregation sites was facilitated by the cooperation of numerous public and private agencies. We are especially grateful to the Florida Power and Light Company, with special thanks to J. R. Wilcox and the environmental affairs offices at the Canaveral, Port Everglades, and Riviera Beach plants. We also are grate- ful for the essential support provided by G. Demuth, Orlando Utilities Commission power plant; A. Sosnow, Port Everglades Port Authority; D. Paul, Blue Spring State Park; C. Shaw, Crystal River National Wildlife Refuge; and T. Linley, Homosassa Springs State Park. Development of the computerized photo-identification system for manatees was made possible by the technical support of R. G. Osborn, D. and D. Batson, H. I. Kochman, and D. Hunter. C. Campbell assisted in updating the database prior to the analysis. J. D. Nichols gave critical guidance to CAL and TJO in our first attempts to estimate survival with mark-recapture methods, and continued to give us advice and support in this analysis. We thank C. Deutsch, L. Ellison, J. D. Nichols, and two journal referees who critically reviewed and improved the manuscript.

\section{Literature Cited}

Ackerman, B. B. 1995. Aerial surveys of manatees: a summary and progress report. Pages 13-33 in T. J. O'Shea, B. B. Ackerman, and H. F. Percival, editors. Population biology of the Florida manatee. U.S. Department of the Interior, National Biological Service, Information and Technology Report 1.

Ackerman, B. B., S. D. Wright, R. K. Bonde, D. K. Odell, and D. J. Banowetz. 1995. Trends and patterns in mortality of manatees in Florida, 1974-1992. Pages 223-256 in T. J. O'Shea, B. B. Ackerman, and H. F. Percival, editors. Population biology of the Florida manatee. U.S. Department of the Interior, National Biological Service, Information and Technology Report 1.

Amstrup, S. C., and G. M. Durner. 1995. Survival rates of radio collared female polar bears and their dependent young. Canadian Journal of Zoology 73:1312-1322.

Anderson, D. R., K. P. Burnham, and G. C. White. 1994. AIC model selection in overdispersed capture-recapture data. Ecology 75:1780-1793.

Arnason, A. N., and K. H. Mills. 1981. Bias and loss of precision due to tag loss in Jolly-Seber estimates for markrecapture experiments. Canadian Journal of Fisheries and Aquatic Sciences 38: 1077-1095.

Beck, C. A., and J. P. Reid. 1995. An automated photoidentification catalog for studies of the life history of the Florida manatee. Pages 120-134 in T. J. O'Shea, B. B. Ackerman, and H. F. Percival, editors. Population biology of the Florida manatee. U.S. Department of the Interior, National Biological Service, Information and Technology Report 1.

Bengtson, J. L. 1981. Ecology of manatees (Trichechus manatus) in the St. Johns River, Florida. Dissertation. University of Minnesota, Minneapolis, Minnesota, USA.

Benton, T. G., and A. Grant. 1996. How to keep fit in the real world: elasticity analysis and selection pressures on life histories in a variable environment. The American Naturalist 147:115-139.

Benton, T. G., A. Grant, and T. H. Clutton-Brock. 1995. Does environmental stochasticity matter? Analysis of red deer life-histories on Rum. Evolutionary Ecology 9:559-574.

Bretagnolle, V., J.-C. Thibault, and J.-M. Dominici. 1994. Field identification of individual ospreys using head marking pattern. Journal of Wildlife Management 58:175-178.

Brownie, C., J. E. Hines, J. D. Nichols, K. H. Pollock, and J. B. Hestbeck. 1993. Capture-recapture studies for multiple strata including non-Markovian transitions. Biometrics 49:1173-1187.

Buckland, S. T. 1990. Estimation of survival rates from sightings of individually identifiable whales. Report of the International Whaling Commission Special Issue 12:149153.

Burnham, K. P., and D. R. Anderson. 1992. Data-based selection of an appropriate biological model: the key to modern data analysis. Pages 16-30 in D. R. McCullough and 
R. H. Barrett, editors. Wildlife 2001: Populations. Elsevier, Amsterdam, The Netherlands.

Burnham, K. P., D. R. Anderson, G. C. White, C. Brownie, and K. H. Pollock. 1987. Design and analysis methods for fish survival experiments based on release-recapture. American Fisheries Society Monograph 5:1-437.

Burnham, K. P., G. C. White, and D. R. Anderson. 1995. Model selection strategy in the analysis of capture-recapture data. Biometrics 51:888-898.

Carothers, A. D. 1973. The effects of unequal catchability on Jolly-Seber estimates. Biometrics 29:79-100.

1979. Quantifying unequal catchability and its effect on survival estimates in an actual population. Journal of Animal Ecology 48:836-869.

Caughley, G. 1966. Mortality patterns in mammals. Ecology 47:906-918.

Charnov, E. L. 1986. Life history evolution in a "recruitment population": why are adult mortality rates constant? Oikos 47:129-134.

Clutton-Brock, T. H., F. E. Guinness, and S. D. Albon. 1982. Red deer: behavior and ecology of two sexes. The University of Chicago Press, Chicago, Illinois, USA.

Eberhardt, L. L. 1977. Optimal policies for conservation of large mammals, with special reference to marine ecosystems. Environmental Conservation 4:205-212.

- 1985. Assessing the dynamics of wild populations. Journal of Wildlife Management 49:997-1012.

Eberhardt, L. L., B. M. Blanchard, and R. R. Knight. 1994. Population trend of the Yellowstone grizzly bear as estimated from reproductive and survival rates. Canadian Journal of Zoology 72:360-363.

Eberhardt, L. L., and T. J. O'Shea. 1995. Integration of manatee life-history data and population modeling. Pages 269 279 in T. J. O'Shea, B. B. Ackerman, and H. F. Percival, editors. Population biology of the Florida manatee. U.S. Department of the Interior, National Biological Service, Information and Technology Report 1.

Eberhardt, L. L., and D. B. Siniff. 1977. Population dynamics and marine mammal management policies. Journal of the Fisheries Research Board of Canada 34:183-190.

Eisenberg, J. F. 1981. The mammalian radiations: an analysis of trends in evolution, adaptation, and behavior. The University of Chicago Press, Chicago, Illinois, USA.

Fowler, C. W. 1981. Comparative population dynamics in large mammals. Pages $437-455$ in C. W. Fowler and T. D. Smith, editors. Dynamics of large mammal populations. John Wiley \& Sons, New York, New York, USA.

Gaillard, J.-M., D. Allaine, D. Pontier, N. G. Yoccoz, and D. E. L. Promislow. 1994. Senescence in natural populations of mammals: a reanalysis. Evolution 48:509-516.

Gaillard, J.-M., D. Delorme, J.-M. Boutin, G. Van Laere, B. Boisaubert, and R. Pradel. 1993. Roe deer survival patterns: a comparative analysis of contrasting populations. Journal of Animal Ecology 62:778-791.

Garrott, R. A., B. B. Ackerman, J. R. Cary, D. M. Heisey, J. E. Reynolds, III, P. M. Rose, and J. R. Wilcox. 1994. Trends in counts of Florida manatees at winter aggregation sites. Journal of Wildlife Management 58:642-654.

Gonzalez, F. T. 1994. The use of photoidentification to study the Amazon River Dolphin, Inia geoffrensis, in the Colombian Amazon. Marine Mammal Science 10:348-353.

Hammond, P. S., S. Mizroch, and G. P. Donovan, editors. 1990. Individual recognition of cetaceans: the use of photographic identification and other techniques to estimate population parameters. Report of the International Whaling Commission Special Issue 12:1-440.

Hargrove, J. W., and C. H. Borland. 1994. Pooled population parameter estimates from mark-recapture data. Biometrics 50:1129-1141.

Hartman, D. S. 1979. Ecology and behavior of the manatee
(Trichechus manatus) in Florida. American Society of Mammalogists Special Publication 5:1-53.

Harvey, P. H., A. F. Read, and D. E. L. Promislow. 1989. Life history variation in placental mammals: unifying the data with theory. Oxford Surveys in Evolutionary Biology 6:13-31.

Harvey, P. H., and R. M. Zammuto. 1985. Patterns of mortality and age at first reproduction in natural populations of mammals. Nature 315:319-320.

Harwood, J., and J. H. Prime. 1978. Some factors affecting the size of British grey seal populations. Journal of Applied Ecology 15:401-411.

Hiby, L., and P. Lovell. 1990. Computer aided matching of natural markings: a prototype system for grey seals. Reports of the International Whaling Commission Special Issue 12: $57-61$.

Hines, J. E., and J. R. Sauer. 1989. Program CONTRAST: a general program for the analysis of several survival or recovery rate estimates. U.S. Fish and Wildlife Service, Fish and Wildlife Technical Report 24:1-7.

Irvine, A. B. 1983. Manatee metabolism and its influence on distribution in Florida. Biological Conservation 25:315334.

Irvine, A. B., J. E. Caffin, and H. I. Kochman. 1982. Aerial surveys for manatees and dolphins in western peninsular Florida. Fishery Bulletin 80:621-630.

Kendall, W. L., J. D. Nichols, and J. E. Hines. 1997. Estimating temporary emigration using capture-recapture data with Pollock's robust design. Ecology 78:563-578.

Laws, R. M. 1966. Age criteria for the African elephant, Loxodonta a. africana. East African Wildlife Journal 4:137.

Le Boeuf, B. J. 1974. Male-male competition and reproductive success in elephant seals. American Zoologist 14: 163-176.

Lebreton, J.-D., K. P. Burnham, J. Clobert, and D. R. Anderson. 1992. Modeling survival and testing biological hypotheses using marked animals: a unified approach with case studies. Ecological Monographs 62:67-118.

Lebreton, J.-D., R. Pradel, and J. Clobert. 1993. The statistical analysis of survival in animal populations. Trends in Ecology and Evolution 8:91-95.

Loison, A., J. M. Gaillard, and H. Houssin. 1994. New insight on survivorship of female chamois (Rupicapra rupicapra) from observation of marked animals. Canadian Journal of Zoology 72:591-597.

Marmontel, M. 1995. Age and reproduction in female Florida manatees. Pages 98-119 in T. J. O'Shea, B. B. Ackerman, and H. F. Percival, editors. Population biology of the Florida manatee. U.S. Department of the Interior, National Biological Service, Information and Technology Report 1.

McClenaghan, L. R., Jr., and T. J. O'Shea. 1988. Genetic variability in the Florida manatee (Trichechus manatus). Journal of Mammalogy 69:481-488.

Millar, J. S., and R. M. Zammuto. 1983. Life histories of mammals: an analysis of life tables. Ecology 64:631-635.

Miththapala, S., J. Seidensticker, L. G. Phillips, S. B. U. Fernando, and J. A. Smallwood. 1989. Identification of individual leopards (Panthera pardus kotiya) using spot pattern variation. Journal of Zoology 218:527-536.

National Oceanic and Atmospheric Administration. 19851993. Climatological data, Florida. National Climatic Data Center, Asheville, North Carolina, USA, 89-97.

Nichols, J. D. 1992. Capture-recapture models: using marked animals to study population dynamics. BioScience 42:94102

Olesiuk, P. F., M. A. Bigg, and G. M. Ellis. 1990. Life history and population dynamics of resident killer whales (Orcinus orca) in the coastal waters of British Columbia and Wash- 
ington State. Report of the International Whaling Commission Special Issue 12:209-243.

O'Shea, T. J. 1988. The past, present, and future of manatees in the southeastern United States: realities, misunderstandings and enigmas. Pages 184-204 in R. R. Odom, K. A. Riddleberger, and J. C. Ozier, editors. Proceedings of the third southeastern nongame and endangered wildlife symposium. Georgia Department of Natural Resources, Game and Fish Division, Social Circle, Georgia, USA.

1995. Waterborne recreation and the Florida manatee. Pages 297-311 in R. L. Knight and K. J. Gutzwiller, editors. Wildlife and recreationists: coexistence through management and research. Island Press, Washington, D.C., USA.

O'Shea, T. J., B. B. Ackerman, and H. F. Percival, editors. 1995. Population biology of the Florida manatee. U.S. Department of the Interior, National Biological Service, Information and Technology Report 1.

O'Shea, T. J., C. A. Beck, R. K. Bonde, H. I. Kochman, and D. K. Odell. 1985. An analysis of manatee mortality patterns in Florida, 1976-1981. Journal of Wildlife Management 49:1-11.

O'Shea, T. J., and W. C. Hartley. 1995. Reproduction and early-age survival of manatees at Blue Spring, Upper St. Johns River, Florida. Pages 157-170 in T. J. O'Shea, B. B. Ackerman, and H. F. Percival, editors. Population biology of the Florida manatee. U.S. Department of the Interior, National Biological Service, Information and Technology Report 1.

O'Shea, T. J., and C. A. Langtimm. 1995. Estimation of survival of adult Florida manatees in the Crystal River, at Blue Spring, and on the Atlantic Coast. Pages 194-222 in T. J. O'Shea, B. B. Ackerman, and H. F. Percival, editors Population biology of the Florida manatee. U.S. Department of the Interior, National Biological Service, Information and Technology Report $\mathbf{1}$.

O'Shea, T. J., and R. L. Reep. 1990. Encephalization quotients and life-history traits in the Sirenia. Journal of Mammalogy 71:531-543.

Paradis, E., G. Guedon, and R. Pradel. 1993. Estimation of sex- and age-related survival rates in a microtine population. Journal of Wildlife Management 57:158-163.

Pollock, K. H., J. D. Nichols, C. Brownie, and J. E. Hines. 1990. Statistical inference for capture-recapture experiments. Wildlife Monographs 107:1-97.

Pradel, R. 1993. Flexibility in survival analysis from recapture data: handling trap dependence. Pages 29-37 in J.-D. Lebreton and P. M. North, editors. Marked individuals in the study of bird population. Birkhauser Verlag, Basel, Switzerland

Pradel, R., J. E. Hines, J.-D. Lebreton, and J. D. Nichols. 1997. Capture-recapture survival models taking account of transients. Biometrics 53:88-100.

Pradel, R., and J.-D. Lebreton. 1993. User's manual for pro- gram SURGE, version 4.2. Centre D'Ecologie Fonctionnelle et Evolutive, CNRS. Montpellier-CEDEX, France.

Promislow, D. E. L. 1992. Costs of sexual selection in natural populations of mammals. Proceedings of the Royal Society of London B247:203-210.

Ralls, K. 1976. Mammals in which females are larger than males. Quarterly Review of Biology 51:245-276.

Ralls, K., R. L. Brownell, Jr., and J. Ballou. 1980. Differential mortality by sex and age in mammals, with specific reference to the sperm whale. Reports of the International Whaling Commission Special Issue 2:233-243.

Rathbun, G. B., J. P. Reid, R. K. Bonde, and J. A. Powell. 1995. Reproduction in free-ranging Florida manatees. Pages 135-156 in T. J. O'Shea, B. B. Ackerman, and H. F. Percival, editors. Population biology of the Florida manatee. U.S. Department of the Interior, National Biological Service, Information and Technology Report 1.

Rathbun, G. B., J. P. Reid, and G. Carowan. 1990. Distribution and movement patterns of manatees (Trichechus manatus) in northwestern peninsular Florida. Florida Marine Research Publication 48:1-33.

Reid, J. P., R. K. Bonde, and T. J. O'Shea. 1995. Reproduction and mortality of radio-tagged and recognizable manatees on the Atlantic coast of Florida. Pages 171-191 in T. J. O'Shea, B. B. Ackerman, and H. F. Percival, editors. Population biology of the Florida manatee. U.S. Department of the Interior, National Biological Service, Information and Technology Report $\mathbf{1}$.

Reid, J. P., G. B. Rathbun, and J. R. Wilcox. 1991. Distribution patterns of individually identifiable West Indian manatees (Trichechus manatus) in Florida. Marine Mammal Science 7:180-190.

Reynolds, J. E., III, and J. R. Wilcox. 1994. Observations of Florida manatees (Trichechus manatus latirostris) around selected power plants in winter. Marine Mammal Science 10:163-177.

Saether, B-E. 1997. Environmental stochasticity and population dynamics of large herbivores: a search for mechanisms. Trends in Ecology and Evolution 12:143-149.

Sandland, R. L., and G. P. Kirkwood. 1981. Estimation of survival in marked populations with possibly dependent sighting probabilities. Biometrika 68:531-541.

Sauer, J. R., and B. K. Williams. 1989. Generalized procedures for testing hypotheses about survival or recovery rates. Journal of Wildlife Management 53:137-142.

Shane, S. H. 1984. Manatee use of power plant effluents in Brevard County, Florida. Florida Scientist 47:180-187.

Trivers, R. L. 1972. Parental investment and sexual selection. Pages 136-179 in B. Campbell, editor. Sexual selection and the descent of man, 1871-1971. Aldine Publishing Company, Chicago, Illinois, USA.

U.S. Marine Mammal Commission. 1995. Annual report of the Marine Mammal Commission, calendar year 1994. A report to Congress. Washington, D.C., USA.

Wooller, R. D., J. S. Bradley, and J. P. Croxall. 1992. Longterm population studies of seabirds. Trends in Ecology and Evolution 7:111-114. 